\title{
PENGARUH KEMAMPUAN E-COMMERCE DAN PROMOSI DI MEDIA SOSIAL TERHADAP KINERJA PEMASARAAN
}

\author{
Deddy Prihadi, Agnes Dwita Susilawati \\ Universitas Pancasakti Tegal
}

\begin{abstract}
Abstrak: Berbagai organisasi terutama organisasi bisnis sudah banyak yang memanfaatkan teknologi internet. Menggunakan teknologi internet merupakan cara yang inovatif dalam melakukan kegiatan perusahaan untuk memasuki pasar di dunia maya yang disebut sebagai electronic commerce (e-commerce). Dengan memanfaatkan teknologi internet, pelaku bisnis dapat melakukan berbagai kegiatan usaha bisnis secara elektronik seperti misalnya transaksi bisnis, berbagi informasi dengan konsumen dan suplier untuk mempertahankan hubungan sebelum, selama dan setelah proses pembelian. Tujuan penelitian ini adalah mengetahui pengaruh kemampuan e-commerce dan promosi di media sosial terhadap kinerja pemasaran pegadang. Sampel dalam penelitian ini adalah pegadang di Pasar Pagi Kota Tegal yang berjumlah 100 orang. Pengolahan data dalam penelitian ini menggunakan analisis regresi. Hasil penelitian ini menunjukkan bahwa: 1) kemampuan e-commerce berpengaruh tidak signifikan terhadap kinerja pemasaran pegadang, 2) promosi di media sosial berpengaruh signifikan terhadap kinerja pemasaran pegadang dan 3) kemampuan e-commerce dan promosi di media sosial secara simultan berpengaruh signifikan terhadap kinerja pemasaran pegadang
\end{abstract}

Kata Kunci: E-Commerce, promosi, kinerja pemasaran

\begin{abstract}
Various business organizations have already take advantage of internet technology. Using internet technology is an innovative way of doing corporate activities for a virtual marketplace called electronic commerce (e-commerce). By utilizing Internet technology, businessesman can conduct various business activities electronically such as business transactions, sharing information with consumers and suppliers to maintain relationships before, during and after the purchase process. The purpose of this research is to investigate the influence of e-commerce capability and promotion in social media on merchant's marketing performance. The sample in this research is merchants at Pasar Tagi Kota Tegal which amount are 100 people. Data processing in this study using regression analysis. The results of this study indicate: 1) the e-commerce capability is not significant to the merchant's marketing performance, 2) promotion in social media significant to the merchant's marketing performance and 3) e-commerce and promotion capability in media social significance simultaneously to merchant's marketing performance.
\end{abstract}

Keywords: E-Commerce, promotion, marketing performance

\section{PENDAHULUAN}

Teknologi internet sudah semakin banyak dimanfaatkan oleh berbagai organisasi terutama organisasi bisnis. Kegiatan dunia usaha menggunakan teknologi internet adalah cara yang inovatif dalam melakukan kegiatan perusahaan untuk memasuki pasar di dunia maya yang disebut sebagai electronic business (e-business) dan electronic commerce (e-commerce) (Tamimi, Sebastianelli \& Rajan, 2005). Dengan memanfaatkan teknologi internet, pelaku bisnis dapat melakukan berbagai kegiatan usaha bisnis secara elektronik seperti misalnya transaksi bisnis, berbagi informasi dengan konsumen dan suplier untuk mempertahankan hubungan sebelum, selama dan setelah proses pembelian.

Pemasaran pada awal abad 21 sedikit demi sedikit mulai mengalami perubahan, peristiwa tersebut ditunjang dengan kegiatan pengembangan di sektor teknologi. Cara berkomunikasi dalam pemasaran juga mendapatkan modernisasi atau perbaikan, berawal dari komunikasi pemasaran secara person-to-person (orang ke orang) hingga terjadinya word-of-mouth saat ini diarahkan pada computer mediated communication dengan new wave technology, yaitu komunikasi berbasiskan pada teknologi 
yang memberikan kemudahan kepada penggunannya untuk mengekspresikan diri dan berkolaborasi dengan pengguna lainnya. Filosofi ini merupakan dasar dari terbentuknya media sosial.

Menurut Kaplan and Haenlein (2010), media sosial merupakan seperangkat aplikasi berbasiskan pada jaringan internet yang didasari oleh Web 2.0, program tersebut yang ditemukan oleh Tim O'reilly (2003). Web 2.0 merupakan suatu platform dasar terbentuknya media sosial, platform ini menyediakan kemudahan bagi penggunanya untuk berkolaborasi secara online dan berbagi (sharing). Media sosial, Facebook dan Twitter, saat ini digunakan untuk menyebarluaskan informasi secara cepat, viral, dan menyebar kepada pengguna internet dalam jumlah yang besar.

Penggunaan platform media sosial di Indonesia berkembang dengan signifikan. Anand Tilak, Head of Facebook Indonesia, mengungkapkan bahwa pengguna aktif Facebook di Indonesia setiap bulannya mencapai 69 juta pengguna (kutipan wawancara Kompas dengan Anand Tilak, 22 September 2014). Hal yang paling penting adalah bagaimana memanfaatkan media sosial dalam mempromosikan atau mengenalkan produk yang ditawarkan kepada konsumen.

Media sosial adalah sebuah fenomena baru yang telah mengubah cara lingkungan bisnis beroperasi. Melalui media social, bisnis mendapatkan akses berkaitan dengan sumber daya yang dinyatakan tidak tersedia bagi pemilik bisnis. Hal ini juga membantu perusahaan untuk meningkatkan kelayakan mereka, memupuk kemitraan strategis dan meningkatkan kontak mereka dengan pelanggan dan pemasok. Hal ini menjadi amat penting bagi pemilik bisnis dan pemasaran untuk memahami bagaimana media social bekerja sebagai alat komunikasi, pemasaran dan bagaimana mereka secara signifikan dapat mengembangkan bisnis mereka (Ambrose Jagongo dan Catherine Kinyua, 2013).

Tujuan penelitian ini adalah untuk mengetahui pengaruh mengetahui pengaruh kemampuan e-commerce dan promosi di media sosial terhadap kinerja pemasaran pegadang di Pasar Pagi Kota Tegal.

\section{TINJAUAN PUSTAKA}

\section{E-Commerce dan Kinerja Pemasaran}

Sistem E-Commerce berkenaan dengan transaksi digital untuk berbagai organisasi dan perorangan (individual), dapat menjangkau konsumen dan masyarakat lebih luas sehingga memiliki peluang untuk meningkatkan pertumbuhan pasar sasarannya (Schneider, 2012). Model transaksi ini memungkinkan transaksi komersial melewati batas negara dan budaya dengan jauh lebih nyaman dan dengan biaya yang lebih efektif daripada dalam kerangka perdagangan yang bersifat tradisional. Mekanisme teknologi tersebut dapat dioperasikan di mana saja untuk semua negara di dunia ini karena memiliki standar yang bersifat universal (Kwahk, 2012).

Kehadiran sistem E-Commerce membuat berbagai perusahaan mikro, kecil maupun menengah dapat memasuki pasar global secara mudah dan bahkan bersifat realtime. Semua pelaku bisnis mudah menjalin hubungan suatu bisnis dengan bisnis lainnya, dan memiliki hubungan langsung dengan konsumen (Li \& Hong, 2013). Sistem E-Commerce sebagai suatu bentuk kemajuan teknologi informasi telah membawa sejumlah perubahan, di antaranya menurunkan biaya interaksi antara pembeli dan penjual, interaksi menjadi lebih mudah tanpa batasan waktu dan tempat, lebih banyak alternatif dan mempermudah promosi, peluang memperluas pangsa pasar tanpa harus memiliki modal dan investasi yang besar, transparansi bisnis dan kemudahan memberikan pelayanan kepada konsumen atau pelanggan (Bernadi, 2013). Dengan menggunakan E-Commerce dapat memperluas pangsa pasar sehingga dapat meningkatkan kinerja pemasaran.

$\mathrm{H}_{1}$ : E-Commerce berpengaruh positif terhadap Kinerja Pemasaran

\section{Promosi di Media Sosial dan Kinerja Pemasaran}

Media sosial merupakan sarana komunikasi untuk dapat berinteraksi, berbagi wawasan antar pengguna dalam skala yang luas. Beberapa contoh jejaring sosial yang paling banyak di gemari masyarakat antara lain Facebook, Twitter, Line, dan You tube. Promosi adalah suatu sistem keseluruhan dari kegiatan-kegiatan bisnis yang ditunjukkan 
untuk merencanakan, menentukan harga, mempromosikan dan mendistribusikan barang dan jasa untuk memuaskan kebutukan baik kepada pembeli yang ada maupun pembeli yang potensial (Swastha dan Irawan, 2008).

Penggunaan strategi promosi melalui media sosial akan menjadikan kinerja pemasaran akan meningkat. Karena dengan penyampaian melalui media sosial, pesan yang disampaikan akan tersebar luas dalam waktu yang sangat singkat, yang secara tidak langsung mempengaruhi pikiran konsumen untuk melihat produk yang disampaikan/ dijual. Penggunaan strategi promosi melalui media sosial yang baik dan tepat merupakan inti dari pemasaran sebuah produk, sebab dengan hal ini pedagang dapat menangkap perhatian dari konsumen dan membuat produk lebih diingat dan tersebar meluas dari orang yang satu ke orang yang lainnya.

$\mathrm{H}_{2}$ : Promosi di Media Sosial berpengaruh positif terhadap Kinerja Pemasaran

Temuan tentang faktor yang mempengaruhi kinerja pemasaran pegadang di Pasar Pagi Kota Tegal dituangkan dalam model empiris kerangka pemikiran mengenai "Pengaruh Kemampuan E-Commerce Dan Promosi Di Media Sosial Terhadap Kinerja Pemasaraan Di Pasar Pagi Kota Tegal”. Model penelitian atau kerangka pemikiran teoritis yang dibangun sebagai berikut:

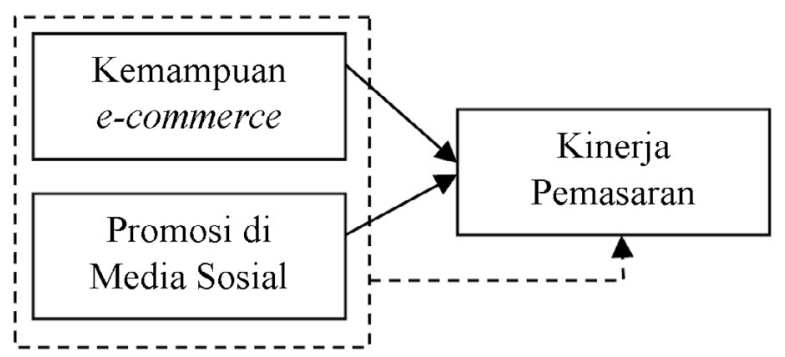

Gambar 1. Kerangka Pemikiran Penelitian

\section{METODE PENELITIAN}

Populasi dalam penelitian ini adalah seluruh pedagang yang ada di Pasar Pagi Kota Tegal, sedangkan untuk sampel ditentukan menggunakan teknik random cluster sampling (random area sampling).

Dalam penelitian ini data yang digunakan dikumpulkan dengan teknik kuesioner dan dokumentasi. Dari kuesioner didapat data mengenai persepsi responden mengenai e-commerce, promosi di media sosial dan kinerja pemasaran. Responden diminta untuk menanggapi pernyataan-pernyataan dengan 5 point model skala Likert, yaitu $5=$ sangat setuju; $4=$ setuju; $3=$ kurang setuju; $2=$ tidak setuju; dan 1 = sangat tidak setuju.

Pada penelitian ini variabel yang diamati terdiri dari dua variabel, variabel bebas yaitu kemampuan E-Commerce dan Promosi di media sosial dan variabel terikat yaitu kinerja pemasaran. Berikut ini akan dijelaskan mengenai operasional variabel dalam penelitian ini:

Tabel 1. Operasional variabel

\begin{tabular}{|c|c|c|}
\hline Variabel & Indikator & Sumber \\
\hline \multirow{3}{*}{$\begin{array}{l}\text { Kemampuan } \\
\text { E-Commerce }\end{array}$} & Jenis e-commerce & \multirow{3}{*}{$\begin{array}{l}\text { Laudon } \\
\text { (2003), } \\
\text { Hidayat } \\
(2008)\end{array}$} \\
\hline & $\begin{array}{l}\text { Komponen } \\
\text { e-commerce }\end{array}$ & \\
\hline & $\begin{array}{l}\text { Standar teknologi } \\
\text { e-commerce }\end{array}$ & \\
\hline \multirow{4}{*}{$\begin{array}{l}\text { Promosi di } \\
\text { Media Sosial }\end{array}$} & Iklan & \multirow{4}{*}{$\begin{array}{l}\text { Tjiptono } \\
(2008), \\
\text { Swastha } \\
(2008)\end{array}$} \\
\hline & Promosi penjualan & \\
\hline & $\begin{array}{l}\text { Penjualan personal } \\
\mathrm{P} \text { e } \mathrm{m} \text { a } \mathrm{s} \text { a } \mathrm{r} \text { a } \mathrm{n} \\
\text { langsung }\end{array}$ & \\
\hline & $\begin{array}{l}\text { Pemasaran dari } \\
\text { mulut ke mulut }\end{array}$ & \\
\hline \multirow[t]{2}{*}{$\begin{array}{l}\text { Kinerja } \\
\text { Pemasaran }\end{array}$} & $\begin{array}{l}\text { Nilai penjualan } \\
\text { P e r t u m bu ha n } \\
\text { penjualan }\end{array}$ & \multirow[t]{2}{*}{$\begin{array}{l}\text { Ferdinand } \\
(2000)\end{array}$} \\
\hline & Porsi pasar & \\
\hline
\end{tabular}

Pengujian instrumen dilakukan dengan uji validitas dan reliabilitas item instrumen akan dilakukan dengan menggunakan software SPSS (Statistical Package For Social Science). Pada penelitian ini, uji validitas yang digunakan adalah uji validitas internal dengan software SPSS dengan menggunakan uji korelasi Pearson Product Moment. Kriteria yang digunakan adalah apabila $\mathrm{r}_{x y}>$ $\mathrm{r}_{\text {tabel }} 5 \%$ maka valid, sedangkan apabila $\mathrm{r}_{x y}^{x y}>$ $\mathrm{r}_{\text {tabel }} 5 \%$ maka tidak valid. Dalam penelitian ini untuk menghitung reliabilitas instrumen dilakukan dengan rumus alpha concrach. Sedangkan dalam menganalisis data akan menggunakan teknik statistik yaitu analisa deskriptif, pengujian asumsi klasik, analisis regresi berganda, pengujian hipotesis berupa uji signifikansi parsial (Uji Statistik t) dan 
uji signifikansi simultan (Uji Statistik F) dan analisis koefisien determinasi.

\section{HASIL DAN PEMBAHASAN}

\section{Deskripsi variabel}

Deskripsivariabel penelitian digambarkan dari nilai indeks dari jawaban responden dengan rentang skor 10 sampai dengan 100 seperti yang tampak pada tabel berikut.

Tabel 2. Indeks Deskriptif Variabel

\begin{tabular}{|c|c|c|}
\hline Variabel & $\begin{array}{c}\text { Indeks \& } \\
\text { Interpretasi }\end{array}$ & $\begin{array}{c}\text { Persepsi } \\
\text { Reponden }\end{array}$ \\
\hline $\begin{array}{l}\text { Kemampuan } \\
\text { E-Commerce }\end{array}$ & $\begin{array}{c}66,47 \\
\text { Sedang }\end{array}$ & $\begin{array}{l}\text { Responden masih } \\
\text { membutuhkan } \\
\text { pengetahuan } \\
\text { pengalaman } \\
\text { dalam } \\
\text { memanfaatkan } \\
\text { teknologi } \\
\text { informasi } \\
\text { baik dalam } \\
\text { bentuk jenis, } \\
\text { penggunaan } \\
\text { maupun alat } \\
\text { teknologi } \\
\text { informasi. }\end{array}$ \\
\hline $\begin{array}{l}\text { Promosi di } \\
\text { Media Sosial }\end{array}$ & $\begin{array}{c}71 \\
\text { Tinggi }\end{array}$ & $\begin{array}{l}\text { Responden } \\
\text { sadar benar } \\
\text { dalam beriklan, } \\
\text { mempromosikan } \\
\text { barang } \\
\text { dagangannya } \\
\text { baik secara } \\
\text { personal maupun } \\
\text { berkelompok } \\
\text { telah } \\
\text { memanfaatkan } \\
\text { media sosial. }\end{array}$ \\
\hline $\begin{array}{l}\text { Kinerja } \\
\text { Pemasaran }\end{array}$ & $\begin{array}{l}\text { 70,20 } \\
\text { Tinggi }\end{array}$ & $\begin{array}{l}\text { Responden } \\
\text { sangat } \\
\text { mengetahui nilai } \\
\text { produk yang } \\
\text { dijualnya, baik } \\
\text { waktu-waktu } \\
\text { kapan produk } \\
\text { tersebut naik } \\
\text { penjualannya. }\end{array}$ \\
\hline
\end{tabular}

\section{Pengujian Asumsi Klasik}

Hasil perhitungan uji normalitas diperoleh nilai signifikansi kolmogorov smirnov dengan unstandardized residual diperoleh nilai sebesar 0,069. Perbandingan antara probability dengan standar signifikansi yang sudah ditentukan diketahui bahwa nilai probability lebih besar dari 0,05. Sehingga menunjukkan bahwa distribusi data dalam penelitian ini normal.

\section{Tabel 3. Hasil Uji Normalitas}

Hasil uji multikolinieritsa menunjukkan untuk kedua variabel independen, angka VIF yaitu masing-masing sebesar 1,411 yang lebih kecil dari 10 sehingga tidak melebihi batas nilai VIF yang diperkenankan yaitu maksimal sebesar 10. Dengan demikian dapat disimpulkan bahwa model regresi tersebut tidak terdapat masalah multikolinearitas.

Tabel 4. Hasil Uji Multikolinearitas

Hasil Multikolinieritas

\begin{tabular}{lcc}
\hline \multicolumn{1}{c}{ Variabel } & Tolerance & VIF \\
\hline $\begin{array}{l}\text { Kemampuan } \\
\text { E-Commerce }\left(\mathrm{X}_{1}\right)\end{array}$ & 0,709 & 1,411 \\
$\begin{array}{l}\text { Promosi di Media Sosial } \\
\left(\mathrm{X}_{2}\right)\end{array}$ & 0,709 & 1,411 \\
\hline
\end{tabular}

Sumber: data primer diolah 2017

Dari gambar di bawah diketahui bahwa tidak ada pola tertentu yang teratur pada grafik scatterplot serta titik-titik menyebar di atas dan di bawah angka 0 pada sumbu Y. Dengan demikian dapat dikatakan bahwa data dalam penelitian ini tidak terjadi heteroskedastisitas.

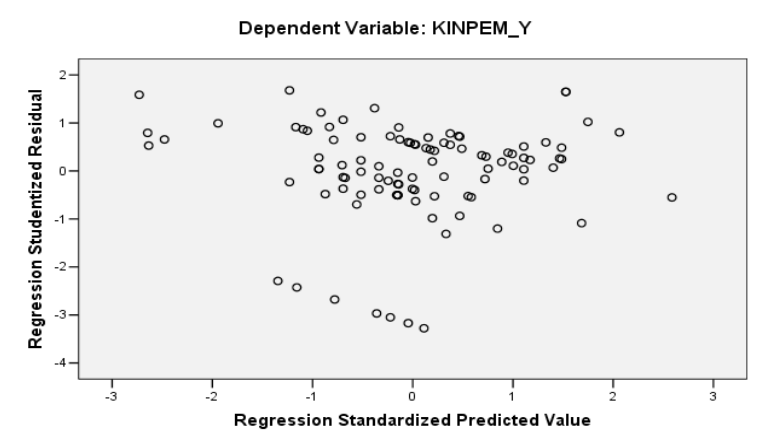

Gambar 2. Hasil Uji Heteroskedastisitas

\section{Analisis Regresi Berganda}

Analisis regresi linier berganda antara variabel yang mempengaruhi dan variabel yang dipengaruhi, dalam hal ini adalah kemampuan e-commerce, promosi di media sosial terhadap kinerja pemasaran. Berdasarkan hasil perhitungan, estimasi model regresi linier berganda antara kemampuan 
e-commerce, promosi di media sosial terhadap kinerja pemasaran diperoleh persamaan $\hat{\mathrm{Y}}=$ $11,122+0,062 \mathrm{X}_{1}+0,525 \mathrm{X}_{2}$.

Tabel 5. Hasil Analisis Regresi Berganda

Hasil Regresi Berganda

\begin{tabular}{cccl}
\hline Variabel & $\mathbf{B}$ & $\mathbf{t}_{\text {hitung }}$ & Sig \\
\hline Konstans & 11,122 & & \\
$\mathrm{X}_{1}$ & 0,062 & 0,864 & 0,390 \\
$\mathrm{X}_{2}$ & 0,525 & 5,261 & $0,000^{* *}$ \\
& & & \\
$\mathrm{~F}$ & $=$ & 23,512 & $0,000^{* *}$ \\
$\mathrm{R}^{2}$ & $=$ & 0,326 & \\
\hline $\begin{array}{c}\text { Sumber: Output SPSS 17.0 Data primer yang } \\
\text { diolah oleh peneliti 2014 }\end{array}$
\end{tabular}

Dari model regresi dapat diartikan bahwa : Nilai a (konstanta) sebesar 11,122 dapat diartikan bahwa jika kemampuan e-commerce, promosi di media sosial bernilai tetap atau konstan maka kinerja pemasaran akan bernilai sebesar 11,122. Koefisien regresi untuk kemampuan e-commerce sebesar 0,062 dan bertanda positif, menyatakan bahwa setiap peningkatan kemampuan e-commerce sebesar $0,062 \%$ maka akan meningkatkan kinerja pemasaran sebesar $0,062 \%$. Koefisien regresi untuk promosi di media sosial sebesar 0,525 dan bertanda positif, menyatakan bahwa setiap peningkatan promosi di media sosial sebesar $0,525 \%$ maka akan meningkatkan kinerja pemasaran sebesar $0,525 \%$.

\section{Pengujan Hipotesis}

Uji statistikt pada dasarnya menunjukkan seberapa jauh pengaruh satu variabel penjelas/independen secara individual dalam menerangkan variasi variabel dependen.

Dari hasil perhitungan uji signifikan parameter individual (uji statistik t) kemampuan e commerce terhadap kinerja pemasaran didapat probabilitas nilai sig sebesar 0,390 maka dapat diartikan bahwa terdapat pengaruh yang tidak signifikan kemampuan e commerce secara parsial terhadap kinerja pemasaran pegadang di Pasar Pagi Kota Tegal, dengan demikian hipotesis pertama tidak dapat diterima kebenarannya.

Dari hasil perhitungan uji signifikan parameter individual (uji statistik t) promosi di media sosial terhadap kinerja pemasaran didapat probabilitas nilai sig sebesar 0,000 maka dapat diartikan bahwa terdapat pengaruh yang signifikan promosi di media sosial secara parsial terhadap kinerja pemasaran pegadang di Pasar Pagi Kota Tegal, dengan demikian hipotesis kedua dapat diterima kebenarannya.

Uji statistik F pada dasarnya menunjukkan apakah semua variabel independen atau variabel bebas yang dimasukkan ke dalam model mempunyai pengaruh secara bersamasama terhadap variabel dependen/terikat.

Dari hasil perhitungan di atas diketahui nilai signifikansi simultan sebesar $0,000<$ 0,05 , artinya kemampuan e-commerce dan promosi di media sosial berpengaruh secara simultan terhadap kinerja pemasaran pegadang di Pasar Pagi Kota Tegal, dengan demikian hipotesis ketiga dapat diterima kebenarannya.

\section{Analisis Koefisien Determinasi}

Berdasarkan hasil analisis dapat diketahui nilai koefisien determinasi sebesar 0,326. Nilai koefisien determinasi sebesar 0,326 tersebut mengandung arti bahwa kemampuan e-commerce dan promosi di media sosial secara simultan memberikan pengaruh atau kontribusi kepada kinerja pemasaran pegadang di Pasar Pagi Kota Tegal sebesar 32,6 \% dan sisanya $67,4 \%$ dipengaruhi oleh faktor lain yang tidak dapat dijelaskan.

\section{KESIMPULAN DAN SARAN}

\section{Kesimpulan}

Berdasarkan analisis data dan pembahasan, dapat disimpulkan bahwa : Kemampuan e-commerce berpengaruh tidak signifikan terhadap kinerja pemasaran pegadang di Pasar Pagi Kota Tegal, terbukti dari hasil uji signifikansi parsial. Promosi di media sosial berpengaruh signifikan terhadap kinerja pemasaran pegadang di Pasar Pagi Kota Tegal. Kemampuan e-commerce dan promosi di media sosial secara simultan berpengaruh signifikan terhadap kinerja pemasaran pegadang di Pasar Pagi Kota Tegal.

\section{Saran}

Saran yang bisa diberikan sehubungan dengan hasil penelitian ini adalah: Sebaiknya diberikan pengenalan mengenai e-commerce agar pedagang pasar pagi dapat bersaing dan tidak tertinggal dengan pebisnis retail modern dan pasar modern, untuk itu perlu 
diberikan pengenalan dan pelatihan mengenai e-commerce yang bisa dilakukan melalui program pengabdian masyarakat. Pedagang pasar pagi sebaiknya mengoptimalkan promosi melalui media sosial agar produk yang dijualnya dapat dikenal oleh masyarakat luas.

\section{DAFTAR PUSTAKA}

Ambrose Jagongo, Catherine Kinyua, 2013. The Social Media and Entrepreneurship Growth. International Journal of Humanities and Social Science Vol. 3 No. 10 (Special Issue May 2013).

Bernadi, J. 2013. Aplikasi Sistem Informasi Penjualan Berbasis Web Pada Toko Velg YQ. ComTech. 4(2). Hlm. 731-741.

Ferdinand, AT. 2000. Manajemen Pemasaran: Sebuah Pendekatan Strategis. Badan Penerbit Undip

Kaplan, Andreas and Michael Haenlein. 2010. Users of the world, unite! The Challenges and Opportunities of Social Media. Kelley School of Business. Business Horizons, Vol. 53, No. 1, pp.59-68

Kwahk, K. Y., \& Ge, X. (2012). The Effects of Social Media on E-Commerce: A Perspective of Social Impact Theory. 45th Hawaii International Conference on System Sciences. ISBN: 978-0-7695-4525-7/12 (C) 2012 IEEE DOI 10.1109/ HICSS.2012.564. Hlm. 1814-1823.

Li, H., \& Hong, J. 2013. Factors Influencing Consumers' Online Repurchasing Behavior: A Review and Research Agenda. iBusiness. 5(4). Hlm.161-166.

Schneider, G. 2012. Electronic Commerce. Tenth Edition. Cengage Learning.

Swastha, Basu DH dan Irawan. 2008. Manajemen Pemasaran Modern. Yogyakarta: Liberty Offset.

Tamimi, N., Sebastianelli, R. \& Rajan, M. 2005. What do online customers value?. Quality Progress, vol. 38(7), pp. 35-39.

Hidayat, Taufik. 2008. Panduan Membuat Toko Online dengan OSCommerce. Jakarta: Mediakita.

Laudon, Kenneth C, dkk, 2003. Sistem Informasi Manajemen. Jakarta: Salemba Empat, Jakarta

Tjiptono, Fandy. 2008. Strategi pemasaran. Yogyakarta: Andi 